\title{
In vitro biosynthesis of organic selenium by Lactobacillus casei from inorganic selenium forms
}

\author{
MOHSENZOMMARA ${ }^{1 *}$,ABD EL-AZIZM.ABD EL-AZIZ ${ }^{1}$, NOHAA. ELGAMMAL ${ }^{1}$, JÓZSEF PROKISCH ${ }^{2}$, \\ SEHAM SWELAM ${ }^{1}$
}

\footnotetext{
${ }^{1}$ Department of Dairy Science, Faculty of Agriculture, Kafrelsheikh University, Kafr El-Sheikh 33516, Egypt.

${ }^{2}$ Faculty of Agricultural and Food Sciences and Environmental Management, Institute of Food Technology, Debrecen University, 4032, Debrecen, Hungary.
}

\begin{abstract}
The bioconversion of selenium in the form of sodium selenite $\left(\mathrm{Na}_{2} \mathrm{SeO}_{3}\right)$ (SeIV) or sodium selenate $\left(\mathrm{Na}_{2} \mathrm{SeO}_{4}\right)(\mathrm{SeVI})$ to organic form by Lactobacillus casei (L. casei) was investigated in vitro. MRS media was supplemented with 1, 2, 5, 10 or $20 \mathrm{ppm}$ of Se, inoculated with $2 \%$ starter culture with about $105 \mathrm{cfu} /$ $m l$ of $L$. casei and then incubated up to $24 \mathrm{hrs}$ at $37^{\circ} \mathrm{C}$. Increasing of selenite "Se(IV)" concentrations in the media markedly reduced the bacterial growth compared to selenate "Se(VI)" indicating cytotoxic effect of selenite. The media supplemented with $5 \mathrm{ppm}$ or more of Se(IV) became reddish after $24 \mathrm{hr}$ of incubation as a result of the formation of 100-200 nanometer particles of selenium (SeNPs). Se speciation of the cultured media supernatants and its corresponding cell fractions was carried out by HPLC-ICP-MS technique. The bioconversion rate of Se to organic form by $L$. casei was extremely higher in $\mathrm{Se}(\mathrm{IV})$ than $\mathrm{Se}(\mathrm{VI})$ in both fractions, however the media supernatant contained the highest content. Increasing the media Se content resulted in gradual increase of organic Se concentration in both cells and supernatant fractions. The medium supplemented with $1 \mathrm{ppm}$ Se(IV) was completely depleted from the inorganic Se as it completely converted to organic form. Although the cell fractions from all Se(VI) supplemented media contained only organic Se, the media supernatant contained significant residual amount of the inorganic form. Our results demonstrate the ability of $L$. casei to convert Se(IV) or Se(VI) up to $20 \mathrm{ppm}$ to organic form(s) either in the cultured media or inside the bacterial cells. However, Se(IV) but not Se(VI), at a limit concentration of 1 ppm, was completely converted and accumulated in an organic form in the cell fraction and the cultured medium.
\end{abstract}

Keywords Lactobacillus casei, sodium selenite, sodium selenate, organic selenium, selenium nanoparticles.

To cite this article: ZOMMARA M, EL-AZIZ AM ABD, ELGAMMAL NA, PROKISCH J, SWELAM S. In vitro biosynthesis of organic selenium by Lactobacillus casei from inorganic selenium forms. Rom Biotechnol Lett. 2021; 26(5): 2916.2925. DOI: 10.25083/rbl/26.5/2916.2925 


\section{Introduction}

The importance of selenium as an essential micronutrient for animals and human nutrition was demonstrated and proved several decades ago. Selenium deficiency in the diet was reported as the main cause of several malnutrition disorders including cancer, cardiovascular disorders, poor immune response, white muscle disease and the osteochondropathy Kashin-Beck disease. Selenium exerts its biological functions through selenoproteins namely selenocysteine. There are twenty-five selenoproteins are encoded in the human genome Kurokawa and Berry (2013). Selenium supplementation is tricky, as high selenium admissions can be dangerous, causing sickness, heaving, muscle fits and even demise, especially if the source is inorganic. Protein-bound selenium is more bioactive and less poisonous than inorganic one and there is enthusiasm for conveying selenium in natural structures in nourishment items requested by customers. Awareness of public health trends and recent scientific evidence of desirable features beyond nutrition stimulates consumer interest and demand for such food. Among the developed selenium enriched products, tea (Xu et al., 2003), table salt (Cheng and Qian, 1990), yoghurt (Achanta et al., 2007), sprout (Lintschinger et al., 2000), infant formula (Tyrala et al., 1996), mushroom (Ogra et al., 2004) onions (Ip and Lisk, 1994), garlic (Ip and Lisk, 1995) and prickly pear fruit (Banuelos et al., 2011). Milk and dairy products, when intended to satisfy particular human dietary demands, can become more appealing and useful. Therefore, production of selenium enriched functional dairy products was the aim of several researches. Enrichment of dairy cows fed with organic selenium is one of the approaches used to increase milk content of organic selenium; therefore the dairy products from such milk could be used to meet the recommended daily intakes of the consumers (Liu et al., 2015). Many Lactic acid bacteria were found to transform and accumulate inorganic Se to organic form in their cultured media and biomass (Prokisch $\boldsymbol{e t}$ al., 2008; Pophaly et al., 2014; Zommara and Prokisch, 2015; Kurek, et al., 2016; Pescuma et al., 2017). In our previous study we have found that yoghurt culture $(S$. thermophiles and L. bulgaricus) cultivated in milk supplemented with sodium selenite Se(IV) was able to accumulate organic Se in the product during the fermentation process at a maximum level of 1 ppm (Zommara and Prokisch, 2015). The aim of the present study is to investigate the ability of $L$. casei to convert the inorganic selenium in the form of selenite $\mathrm{Se}(\mathrm{IV})$ or selenite $\mathrm{Se}(\mathrm{VI})$ to organic form in the cultured media supplemented with different concentrations of Se. The bacterial growth rate was followed up to $24 \mathrm{hr}$ of incubation period and speciation of Se forms was carried out in the media supernatant and the lysozyme hydrolyzed cell pellets using HPLC-ICP-MS system.

\section{Materials and methods}

\section{Cultivation of Lactobacillus casei with selenium sources}

Pure lyophilized culture of Lactobacillus casei NCAIM B 1147 (L. casei) strain was obtained from the National
Collection of Agricultural and Industrial Microorganisms, Budapest, Hungary. The bacterial culture (2\%) with about $10^{5} \mathrm{cfu} / \mathrm{ml}$ was cultivated in MRS broth medium as described by De-Man et al., (1960) amended with 0, 1, 2, 5, 10 and $20 \mathrm{ppm}$ of filter sterilized (Sartorius AG, Germany) sodium selenite, $\mathrm{Na}_{2} \mathrm{SeO}_{3}$. $5 \mathrm{H}_{2} \mathrm{O}$ [Se(IV)], or sodium selenate, $\mathrm{Na}_{2} \mathrm{SeO}_{4} .10 \mathrm{H}_{2} \mathrm{O}$ [Se(VI)] Sigma-Aldrich, Switzerland) and incubated at $37^{\circ} \mathrm{C}$ up to $24 \mathrm{~h}$.

\section{Determination of bacterial growth}

The bacterial growth was monitored at $2 \mathrm{hr}$ intervals for $12 \mathrm{hr}$ and then after $24 \mathrm{hr}$ of incubation the cultured media. The bacterial growth was estimated by measuring the absorbance at $650 \mathrm{~nm}$ (Ayad et al., 2004) and determination the $\mathrm{pH}$ value (Radelkis Electrochemical Instruments, Hungary) of the media.

\section{Analysis of selenium species in medium supernatant and cell fraction}

Ten $\mathrm{ml}$ aliquots of media were removed after $24 \mathrm{hr}$ of incubation. The media were centrifuged at $4500 \mathrm{~g}$ (7000 rpm) for $20 \mathrm{~min}$ at $10^{\circ} \mathrm{C}$ to spin down the bacterial cells. The supernatant was carefully collected and kept under freezing for Se speciation analysis. The cell pellets were washed 2 times by Tris- $\mathrm{HCl}$ buffer $(50 \mathrm{mM}, \mathrm{pH} 7.5)$ and finally with ultra-pure water. To the cell pellet $1 \mathrm{ml}$ Tris-HCl buffer (10 mM, pH 8.0) was added followed by $100 \mu \mathrm{l}$ of $10 \%$ lysozyme solution (Sigma-Aldrish, $100.000 \mathrm{U} / \mathrm{mg}$ ) and incubated overnight at room temperature. The hydrolyzed cell pellet was centrifuged at $5000 \mathrm{~g}$ for $20 \mathrm{~min}$ and the supernatant was collected (cell fraction) for Se speciation analysis. Media supernatant and the cell fractions were analyzed for Se species by inductively coupled plasma mass spectrometer (ICP-MS) (X series, Thermo Fisher Scientific, Germany) coupled to HPLC (Merk-Hitachi L06200A, Germany) equipped with an anion exchange chromatography column (Polyspher, IC-ANI, Merck, Germany) as previously described (Zommara et al., 2007). Se (10 ppb) standards mixture namely; seleno-L-methionine (SeMet, Fluka Chemie, Switzerland), Se(IV) and Se(IV) were prepared in Milli-Q water.

\section{Scanning electron microscopy (SEM), transmission electron microscopy (TEM) and SeNPs size determination}

The SEM and TEM of the bacterial media were carried out according to Nagy et al., (2016) using Hitachi S 4300 SEM (Schaumburg, IL, USA) and TESLA BS 540 TEM (Brno, Czechoslovakia). Size of the SeNPs was determined by particle size analyzer (Malvern, Mastersizer 2000) Malvern Instruments Ltd, UK.

\section{Results and discussion}

Data illustrated in Fig. 1 (A \& B) show the growth profile of L. casei strain incubated in MRS media with different concentration of Se(IV). The bacterial growth rate was monitored during $24 \mathrm{hr}$ of incubation using the progress of medium acidity and absorbance as indicators. The $\mathrm{pH}$ data indicated no inhibition effect of Se(IV) on bacterial growth 
up to $5 \mathrm{ppm}$ in the medium. However, addition of 10 and $20 \mathrm{ppm}$ to the medium had a slight negative effect on bacterial growth. The media absorbance confirmed the $\mathrm{pH}$ data although the media amended with 10 and 20 ppm Se(IV) resulted in high absorbance after $4 \mathrm{hr}$ of incubation compared to the media with less $\mathrm{Se}(\mathrm{IV})$ content. This increase may be explained by the accumulation of selenium nanoparticles (SeNPs) in the cells and media (Fig. 2 A \& B). The transmission electron microscope (TEM) photo of a bacterial cell (Fig. $2 \mathrm{~A}$ ) and The scanning electron microscope (SEM) photo of the medium amended with 20 ppm Se(IV) (Fig. 2 B) showed the accumulation of SeNPs inside the bacterial cells and in the cultured medium, respectively. In this respect, Alzate et al., (2010) stated that supplementation of fermented milk with Se(IV) below 2 ppm had no negative effect in the growth of a mixed cultures of S. thermophilus,
L. bulgaricus, L. casei, L. paracasei and B. Lactis until the 4 th week of cold storage. They noticed segregated selenium as SeNPs in the fermented milk supplemented with 6, 10 and $20 \mathrm{ppm} \mathrm{Se}(\mathrm{IV})$. Our previous studies showed that different LAB including the traditional yoghurt culture $(S$. thermophilus and L. bulgaricus) and bifidobacteria were able to accumulate SeNPs when cultivated in suitable media amended with different concentrations of Se(IV) up to 20 ppm. (Prokisch et al., 2008; Prokisch and Zommara, 2010; Zommara and Prokisch, 2015). The ability of lactic acid bacteria to biotransform selenite Se(IV) to organic form(s) have been reported in plenty of research papers including different strains of lactobacilli and the traditional yoghurt starter culture (Pophaly et al., 2014; Kurek, et al., 2016; Pescuma et al., 2017).
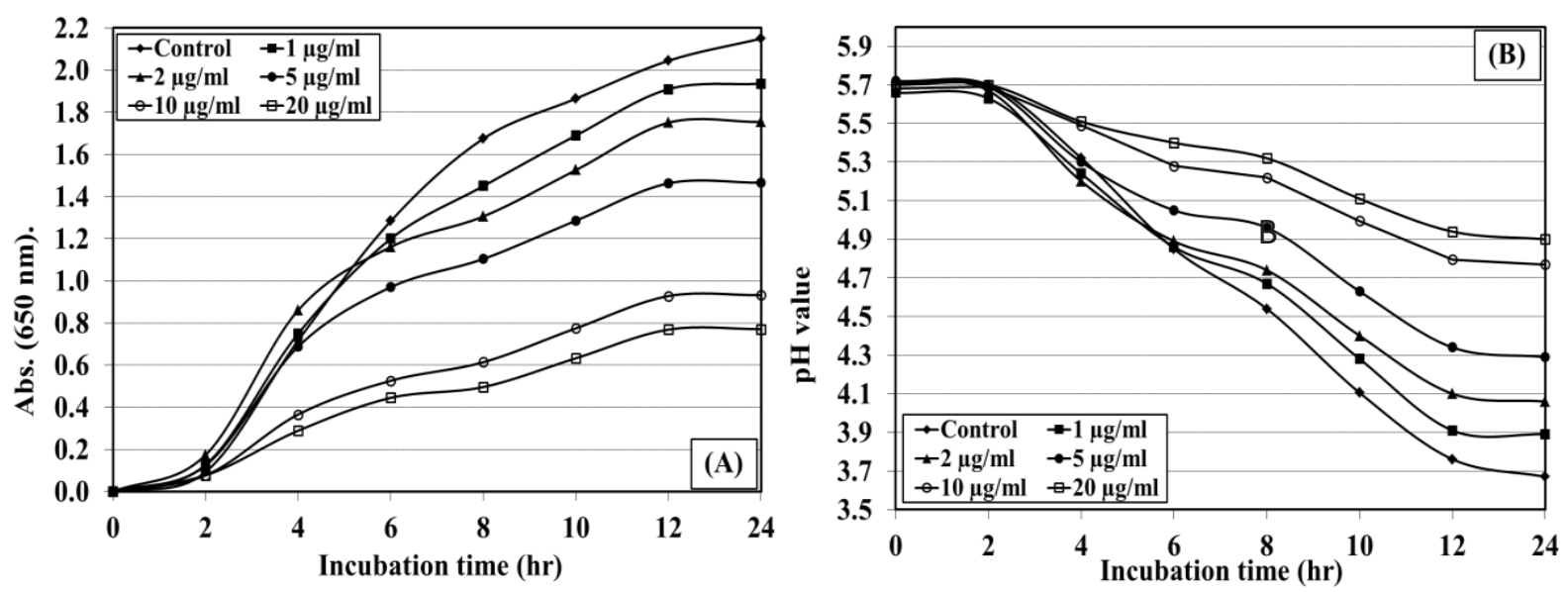

Figure 1. Effect of selenium (IV) concentration on growth of L. casei cultured in MRS broth media during $24 \mathrm{hr}$. of incubation at $37^{\circ} \mathrm{C}$ as indicated by cultured media absorbance (A) and $\mathrm{pH}$ value (B).
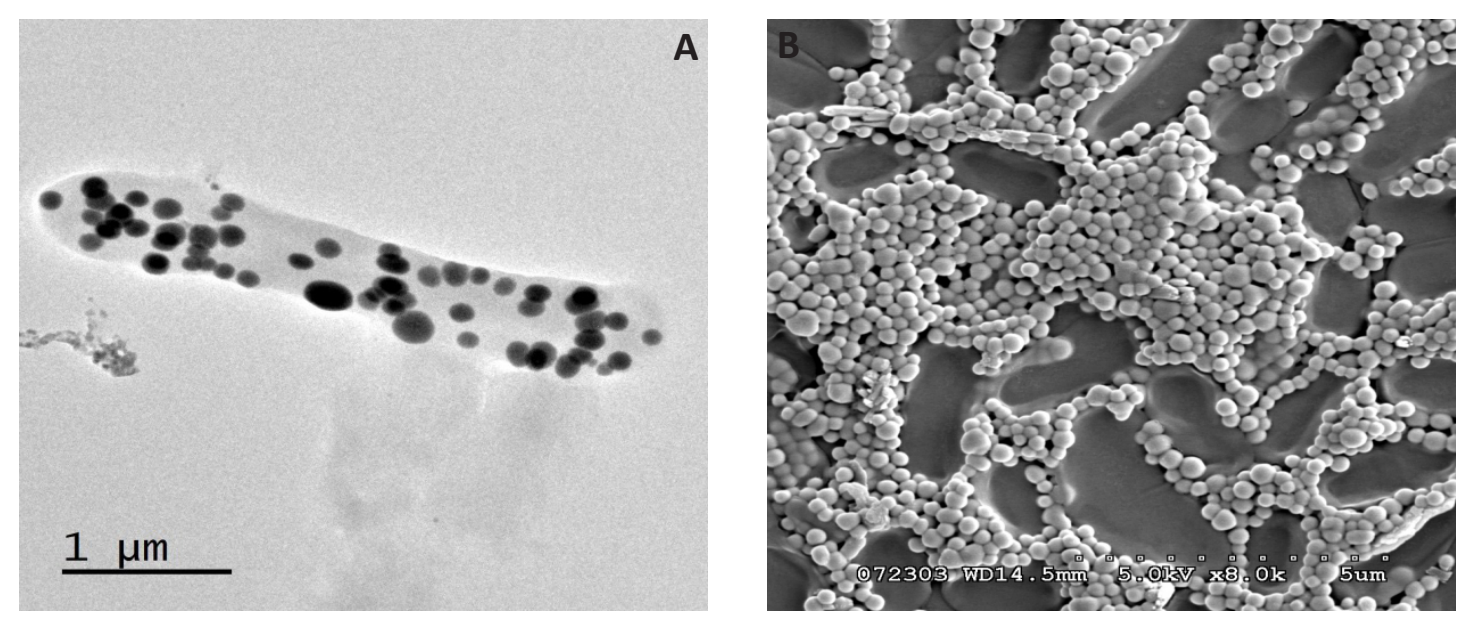

Figure 2. TEM of a single cell (A) and SEM of the cultured media (B) of L. casei cultivated in MRS media with 20 ppm of $\mathrm{Se}(\mathrm{IV})$ and incubated at $37^{\circ} \mathrm{C}$ for $24 \mathrm{hr}$ showing SeNPs inside (A) and outside (B) the cells.

On the other hand, there was no inhibition effect of $\mathrm{Se}(\mathrm{VI})$ on the growth of $L$. casei as indicated by following the media absorbance and pH (Fig. 3 A \& B), respectiveley although, the bacterial growth rate was slightly reduced in the medium supplemented with $20 \mathrm{ppm} \mathrm{Se(VI).} \mathrm{Unlike}$ $\mathrm{Se}(\mathrm{IV})$, use of $\mathrm{Se}(\mathrm{VI})$ did not led to accumulate SeNPs inside the cells or outside in the cultured media (data not shown). 

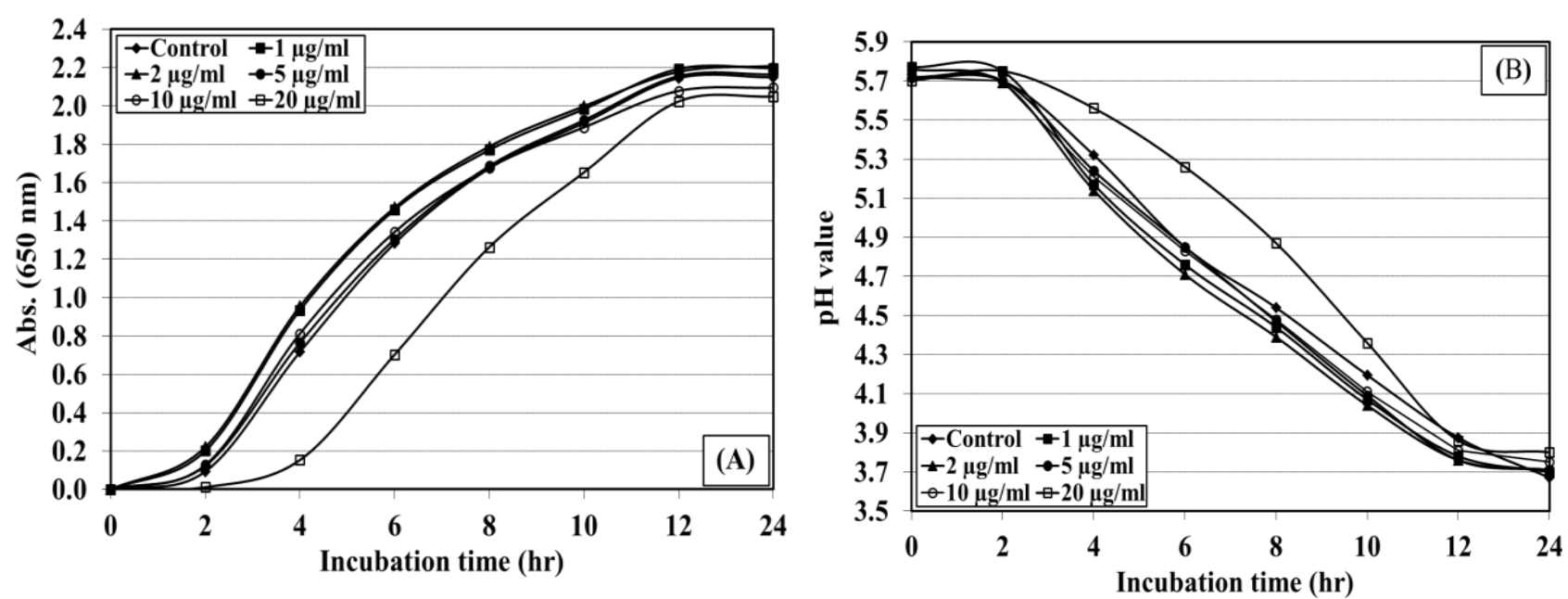

Figure 3. Effect of selenium (VI) concentration on growth of $L$. casei cultured in MRS broth media during $24 \mathrm{hr}$ of incubation at $37^{\circ} \mathrm{C}$ as indicated by cultured media absorbance (A) and $\mathrm{pH}$ value (B).

The ability of L. casei to convert different concentrations of $\mathrm{Se}(\mathrm{IV})$ to organic form in MRS media supernatant and cell biomass are shown in Fig. (4) and Fig. (5). The data illustrated in Fig. (4) clearly show that most of Se(IV) in the cultured media was converted to an organic form during the incubation period (24hr.). However, The medium supplemented with $1 \mathrm{ppm}$ almost depleted from the inorganic $\mathrm{Se}(\mathrm{IV})$. On the other side, the bacterial cell fractions had higher concentration of organic Se (Fig. 5) compared to its corresponding cultured medium supernatant (Fig. 4). Except for the medium supplemented with 20 ppm Se(IV), selenium was almost detected in an organic form inside the bacterial cell.

The formation of organic selenium takes place by replacing sulfur with $\mathrm{Se}$ in the sulfied amino acids in the proteins namely cysteine and methionine to form selenocysteine(Se-cys) and selenomethionine (Se-met) as the main organic selenium species found in plant and animal tissue (Alzate et al., 2007; Alzate et al., 2008; Galano et al., 2013; Palomo et al., 2014; Pescuma et al., 2017). Also, the production of SeNPs by L. casei cultivated in suitable medium supplemented with Se(IV) was repeatedly confirmed by many researchers (Nagy et al., 2016; Rajasree and Gayathri, 2015; Eszenyi et al., 2011). Our results demonstrated that L. casei produce SeNPs with 100-200 nm dimeter when cultivated with MRS media amended with Se(IV). Diowksza et al., (1999) also observed a red color in L. plantarum, L. brevis, L. sanfrancisco biomass grown in MRS medium amended with Se(IV) exceeding 10 ppm. The formation of SeNPs by the bacterial cultures may be attributed to a detoxification mechanism (Prokisch et al., 2008).

The bacterial cell fraction of the medium fortified with 1 ppm Se(IV) contained no inorganic selenium which indicate a complete conversation of Se(IV) to organic form at that concentration or less. In this respect, Prokisch et al., (2008) and Zommara and Prokisch (2015) stated that whey media cultivated with yoghurt culture (S. thermophilus and L. bulgaricus) and different concentrations of Se(IV) markedly increased the organic form of selenium in the supernatant. On contrast, L. casei showed weak ability to convert Se(VI) to an organic form compared to Se(IV). The data illustrated in Fig. (6) and Fig. (7) obviously show the remaining of high residual content of $\mathrm{Se}(\mathrm{VI})$ in the cultured medium supernatant (Fig. 6); however, all the Se detected in the cell fraction was in the organic form (Fig. 7).

\section{Conclusion}

In conclusion, The obtained results indicate that L. casei could be used as Se enriched probiotic culture using Se(IV) or $\mathrm{Se}(\mathrm{VI})$ up to $20 \mathrm{ppm}$ with superior to $\mathrm{Se}(\mathrm{IV})$, or as a starter culture for producing Se rich fermented dairy foods using $\mathrm{Se}(\mathrm{IV})$ at a limit concentration of $1 \mathrm{ppm}$. Also, in higher $\mathrm{Se}(\mathrm{IV})$ concentration $L$. casei produces SeNPs which may be applied in different applications, however more adequate research still in need in this regard. 

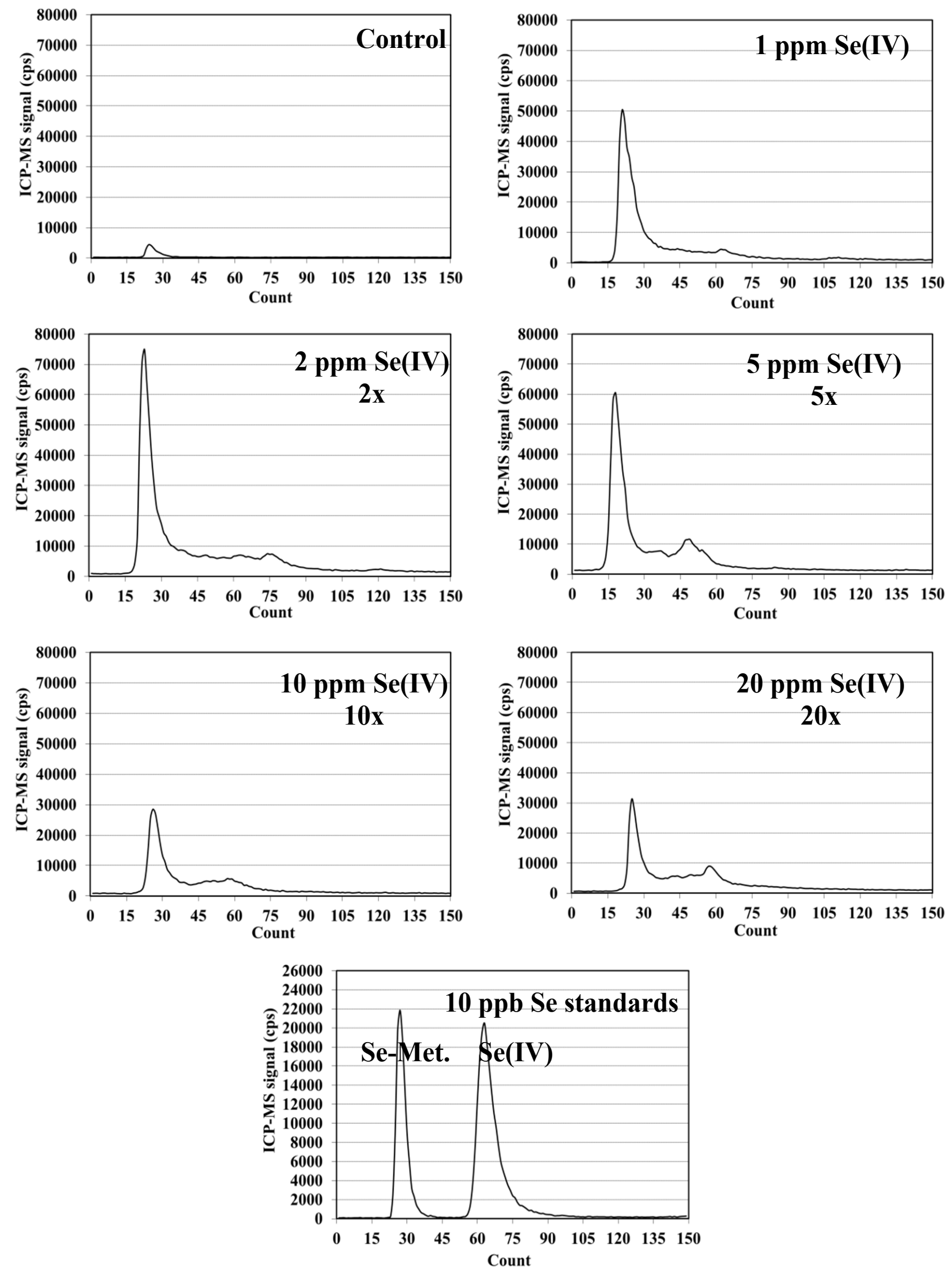

Figure 4. Selenium content in MRS media supernatant of $L$. casei incubated with different concentrations of $\mathrm{Se}(\mathrm{IV})$ at $37^{\circ} \mathrm{C}$ for $24 \mathrm{hr}$ measured as count per second (cps). 

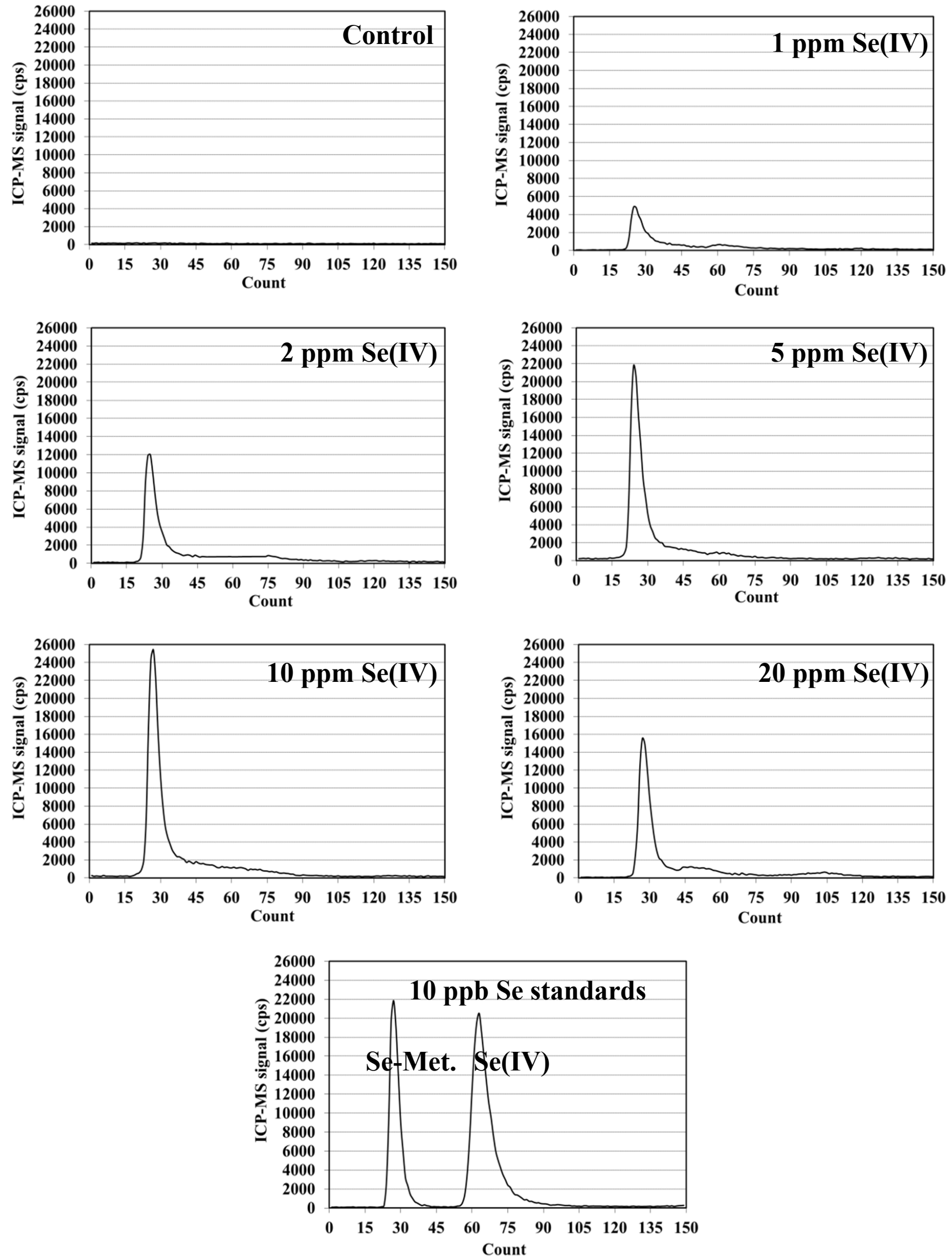

Figure 5. Selenium content in cell fraction of L. casei incubated in MRS media with different concentrations of $\mathrm{Se}(\mathrm{IV})$ at $37^{\circ} \mathrm{C}$ for $24 \mathrm{hr}$ measured as count per second (cps). 

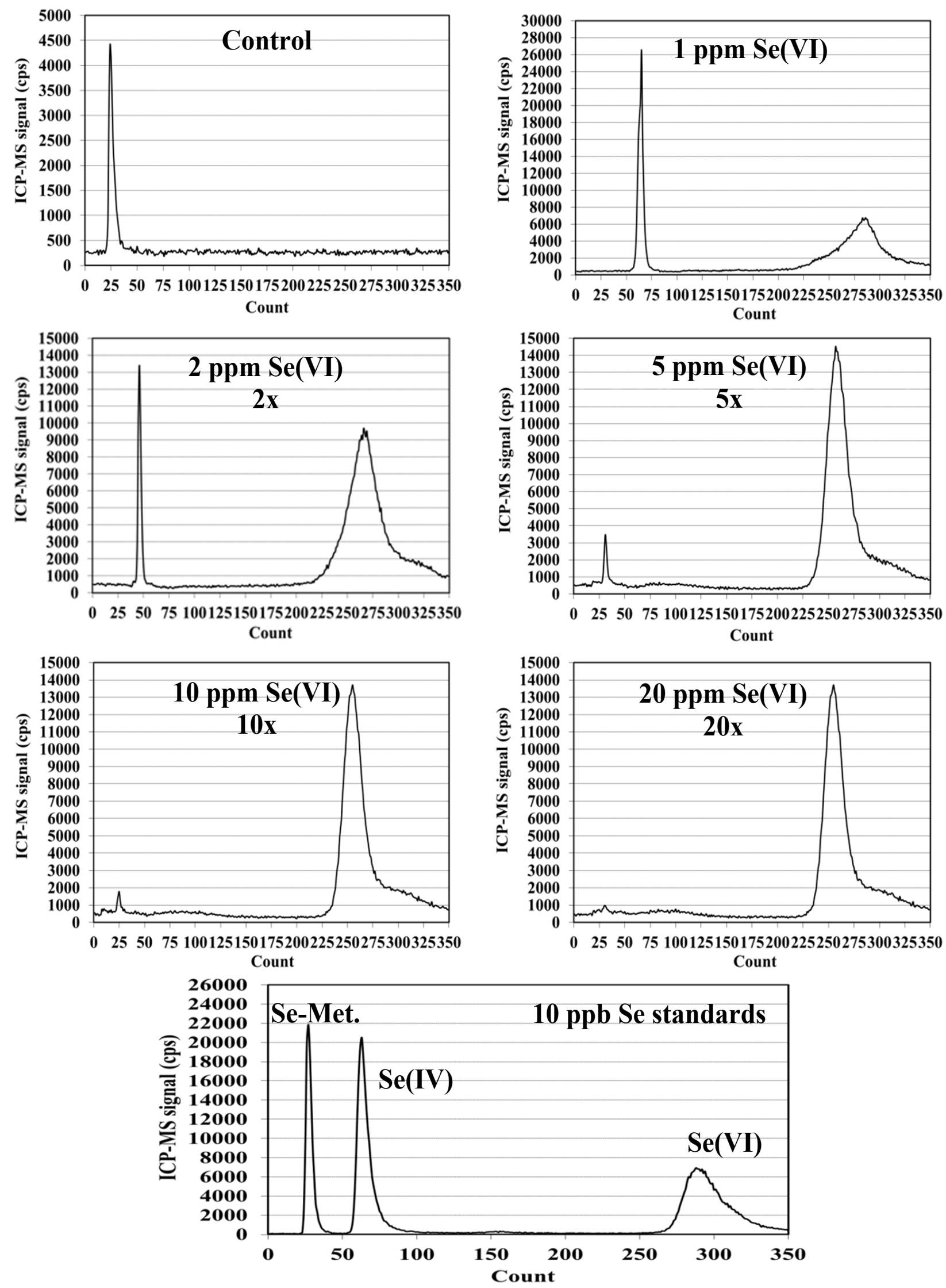

Figure 6. Selenium content in MRS media supernatant of $L$. casei incubated with different concentrations of $\mathrm{Se}(\mathrm{VI})$ at $37^{\circ} \mathrm{C}$ for $24 \mathrm{hr}$ measured as count per second (cps). 

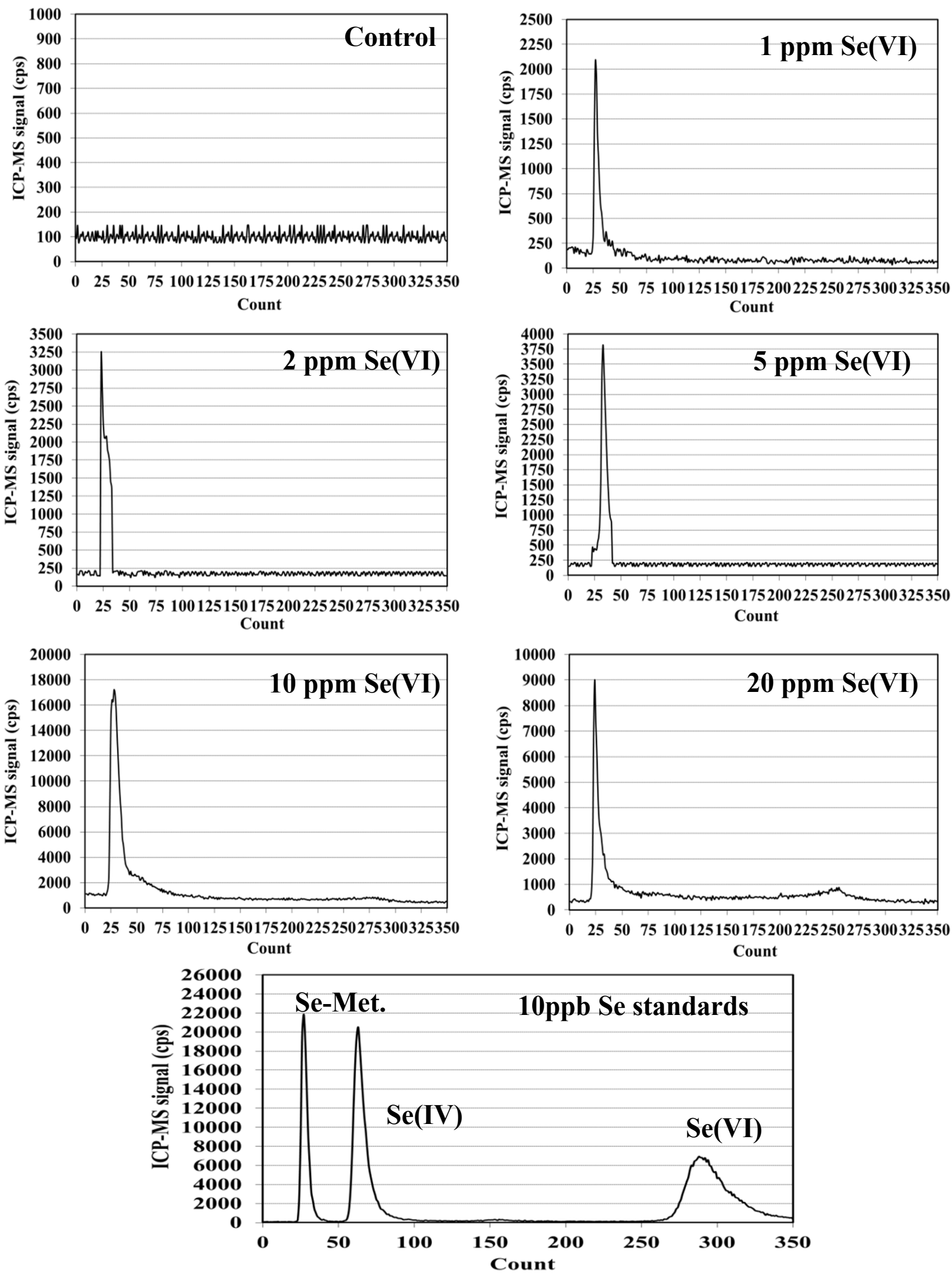

Figure 7. Selenium content in cell fraction of L. casei incubated in MRS media with different concentrations of $\mathrm{Se}(\mathrm{VI})$ at $37^{\circ} \mathrm{C}$ for $24 \mathrm{hr}$ measured as count per second (cps). 


\section{References}

1. Achanta, K., Aryana, K. J., \& Boeneke, C. A. (2007). Fat free plain set yogurts fortified with various minerals. LWT-Food Sci. Tech., 40(3): 424-429. https://doi. org/10.1016/j.lwt.2006.01.001

2. Alzate, A., Cañas, B., Pérez-Munguí, S., HernándezMendoza, H., Pérez-Conde, C., Gutiérrez, A.M., \& Cámara, C. (2007). Evaluation of the inorganic selenium biotransformation in selenium-enriched yogurt by HPLC-ICP-MS, J. Agric. Food Chem., 55(24), 9776-9783. https://doi.org/10.1021/jf071596d

3. Alzate, A., Fernández-Fernández, A., Pérez-Conde, C., Gutiérrez, A.M.,\& Cámara C. (2008). Comparison of biotransformation of inorganic selenium by lactobacillus and saccharomyces in lactic fermentation process of yogurt and kefir, J. Agric. Food Chem., 56(18), 8728-8736. https://doi.org/10.1021/jf8013519

4. Alzate, A., Pérez-Conde, M.C., Gutiérrez, A.M., \& Cámara, C. (2010). Selenium-enriched fermented milk: A suitable dairy product to improve selenium intake in humans. Int. Dairy J., 20(11), 761-769. https:// doi.org/10.1016/j.idairyj.2010.05.007

5. Ayad, E. H. E.; Nashat, S.; El-Sadek, N.; Metwaly, H. and El-Soda. M. (2004). Selection of wild lactic acid bacteria isolated from traditional Egyptian dairy products according to production and technological criteria. Food Microbiol., 21(6): 715-725. https://doi. org/10.1016/j.fm.2004.02.009

6. Banuelos, G. S., Fakra, S. C., Walse, S. S., Marcus, M. A., Yang, S. I., Pickering, I. J., Bilon-smith \& Freeman, J. L. (2011). Selenium accumulation, distribution, and speciation in spineless prickly pear cactus: a droughtand salttolerant, selenium-enriched nutraceutical fruit crop for biofortified foods. Plant Physiology, 155(1): 315-327. https://doi.org/10.1104/pp.110.162867

7. Cheng, Y. Y., and Qian, P. C. (1990). The effect of selenium-fortified table salt in the prevention of Keshan disease on a population of 1.05 million. Biomed. Environ. Sci., 3(4): 422-428.

8. De-Man J., Rogosa M.,\& Sharpe M., (1960). A medium for the cultivation of lactobacilli. J. Appl. Bacteriol., 23(1), 130-135.https://doi. org/10.1111/j.1365-2672.1960.tb00188.x

9. Diowksza, A., Ambroziak, W., \& Wlodarczyk, M. (1999). Investigation of the ability of selenium accumulation by lactic acid bacteria of Lactobacillus species and yeast Saccharomyces cerevisiae. J. Food Nutr. Sci., 8(1): 17-22.

10. Eszenyi, P., Sztrik, A., Babka, B., \& Prokisch, J. (2011).Elemental, nano-sized (100-500 nm) selenium production by probiotic lactic acid bacteria.Int. J. Biosci. Biochem.Bioinform.,1(2), 148-152. https:// doi.org/10.7763/IJBBB.2011.V1.27

11. Galano, E., Mangiapane, E., Bianga, J., Palmese, A., Pessione, E., Szpunar, J., Lobinski, R., \& Amoresano, A. (2013). Privileged incorporation of selenium as selenocysteine in lactobacillus reuteri proteins demonstrated by selenium-specific imaging and proteomics, Mol. Cell. Proteomics, 12(8) 2196-2204. https://doi.org/10.1074/mcp.M113.027607

12. Ip, C., \& Lisk, D. J. (1994). Enrichment of selenium in allium vegetables for cancer prevention. Carcinogenesis, 15(9): 1881-1885. https://doi. org/10.1093/carcin/15.9.1881

13. Ip, C., \& Lisk, D. J. (1995). Efficacy of cancer prevention by high selenium garlic is primarily dependent on the action of selenium. Carcinogenesis, 16(11): 26492652. . https://doi.org/10.1093/carcin/16.11.2649

14. Kurek, E., Ruszczyńska, A., Wojciechowski, M., Luciuk, A., Michalska-Kacymirow, M., Motyl, I. \& Bulska, E. (2016). Bio-transformation of selenium in Se-nriched bacterial strains of Lactobacillus casei. Rocz. Panstw. Zakl. Hig., 67(3): 253-262.

15. Kurokawa, S. \& Berry, M. J. (2013). "Selenium. Role of the Essential Metalloid in Health". Met Ions Life Sci., 13: 499-534. https:// doi:10.1007/978-94-007-7500-8_16.

16. Lintschinger, J., Fuchs, N., Moser, J., Kuehnelt, D., \& Goessler, W. (2000). Selenium-enriched sprouts. A raw material for fortified cereal-based diets. J. Agric. Food Chem., 48(11): 5362-5368. https://doi:10.1021/ jf000509d

17. Liu, H. Y., Zhu, W. Z., Lu, B. Y., Wei, Z. H. \& Ren, D. X. (2015). Effect of feed selenium supplementation on milk selenium distribution and Mozzarella quality. J. Dairy Sci., 98(12): 8359-8367. http://dx.doi. org/10.3168/jds.2015-9676

18. Loualeche, H., Bracquart, P., Saulnier, F., Desmazeaud, M., \& Linden, G. (1993) Carbon dioxide effects on the growth and metabolites of morphological variants of Streptococcus thermophilus. J. Dairy Sci., 76(12), 3683-3689. https://doi.org/10.3168/jds. S0022-0302(93)77710-3

19. Nagy, G. Pinczes, G., Pinter, G., Pocsi, I., Prokisch, J., \& Banfalvi, G. (2016). In situ electron microscopy of lactomicroselenium particles in probiotic bacteria. Int. J. Mol. Sci., 17(7), 1-8. https://doi.org/10.3390/ ijms17071047

20. Ogra, Y., Ishiwata, K., Encinar, J. R., qobinski, R., \& Suzuki, K. T. (2004). Speciation of selenium in selenium-enriched shiitake mushroom, Lentinula edodes. Anal. Bioanal. Chem., 379(5-6): 861-866. https://doi. org/10.1007/s00216-004-2670-6

21. Palomo, M., Gutiérrez, A.M., Pérez-Conde, M.C., Cámara, C., \& Madrid Y. (2014) Se metallomics during lactic fermentation of Se-enriched yogurt. Food Chem., 164(1), 371-379. https://doi.org/10.1016/j. foodchem.2014.05.007

22. Pescuma, M., Gomez-Gomez, B., Perez-Corona, T., Font, G., Madrid, Y., \& Mozzi, F. (2017). Food prospects of selenium enriched-Lactobacillus acidophilus CRL 636 and Lactobacillus reuteri CRL 1101. J. Funct. Foods, 35, 466-473. https://doi.org/10.1016/j. jff.2017.06.009

23. Pophaly, S.D., Poonam,Singh, P., Kumar, H., Tomar, S.K, \& Singh, R. (2014). Selenium enrichment of lactic acid bacteria and bifidobacteria: A functional food 
perspective. Trends Food Sci. Tech. 39(2), 135-145. http://dx.doi.org/10.1016/j.tifs.2014.07.006

24. Prokisch, J. \& Zommara, M. A. (2010). Process for producing elemental selenium nanospheres, United States Patent 20100189634.

25. Prokisch, J., Széles, É., Kovács, B., Daróczy, L. \& Zommara, M. (2008). Formation of metal selenium nanospheres in bacteria: Is it a possible detoxification mechanism? Cereal Res. Commu., 36. Suppl. (5), 947952. http://dx.doi.org/10.1556/CRC.36.2008.Suppl.1

26. Rajasree, S. R. R. \& Gayathri, S. (2015). Extracellular biosynthesis of selenium nanoparticles using some species of lactobacillus. Indian J. Geo-Marine Sci., 43(5): 766-775.

27. Tyrala, E. E., Borschel, M. W., \& Jacobs, J. R. (1996). Selenate fortification of infant formulas improves the selenium status of preterm infants. Am. J. Clin. Nutr., 64(6): 860-865. https://doi.org/10.1093/ajcn/64.6.860

28. Xu, J., Zhu, S., Yang, F., Cheng, L., Hu, Y., Pan, G., et al. (2003). The influence of selenium on the antioxidant activity of green tea. J. Sci. Food Agric., 83(5): 451455. https://doi.org/10.1002/jsfa.1405

29. Zommara, M. A., Prokisch, J., Széles, E. \& Zoltán, G. (2007). Utilization of whey from the manufacture of Kareish cheese enriched with organic selenium in bread making. The 10th Int. Conf. for Dairy Sci. and Tech., 549-564, 19-21, November, Cairo.

30. Zommara, M. \& Prokisch, J. (2105). Selenium rich yoghurt: Bio-fortification for better health. Egyptian J. Dairy Sci., 43(2): 159-167. 